\title{
Meiotic Behaviour and Nuclear DNA Variation in Some Species of Mammillaria (Cactaceae)
}

\author{
A. B. Das, S. Mohanty and P. Das \\ Cytogenetics Laboratory, Regional Plant Resource Centre, \\ Bhubaneswar 751015, Orissa, India
}

Accepted June 9, 1997

Mammillaria of the family Cactaceae, a large family of perennial xerophytic plants has 62 species in India with varieties, cultivars and forms of horticultural importance (Das and Panda 1995, Panda and Das 1995). The genus is widely distributed in Mexico, South of USA, Greater and Lesser Antilles and Coast of Venezuela (Cullmann et al. 1986). Mammillarias are fairly small cacti, usually globular or elongated with small flowers arranged usually in a ring around the crown. Fruits are smooth, juicy, club shaped, with berries mostly of brilliant red colour (Heywood 1985). The somatic chromosome analysis showed $2 \mathrm{n}=22$ in $M$. bocasana, $M$. hahniana, M. rhodantha and M. zeilmanniana (Katagiri 1952, Remski 1954). To ascertain the DNA diversity in different species of Mammillaria, understanding of the interspecific variation, if any, is necessary. The meiotic behaviour and chiasma frequency are the major basic information in the conventional breeding programme for creation of new hybrids of horticultural interest. Interspecific chromosome pairing behavior, genomic compatibility and nuclear DNA content has not been studied in the genus Mammillaria earlier. The present study principally deals with the 4C DNA estimation in relation to genomic behavior in 8 species of Mammillaria.

\section{Materials and methods}

Young and fresh flower buds of 8 species of Mammillaria namely $M$. bocasana Pos., $M$. boolii Linds., M. grandiflora Otto \& Pfeiffer, M. hahniana Werd., M. occidentalis (Br. and R.) Bod., M. plumosa Web., M. rhodantha Lk. \& O. and M. zeilmanniana Bod. were collected from the experimental cactus garden of Regional Plant Resource Centre, Bhubaneswar. Flower buds were fixed overnight in propionic acid:ethanol $(1: 3)$ at room temperature and kept in $70 \%$ ethanol for meiotic studies. Random scoring of chiasma frequencies was done in at least very clear five pollen mother cells (PMCs) showing well-spread bivalents in diakinesis stage of meiotic prophase I stage from ten different plants in each species. Aceto-carmine (2\%) was used for staining in meiotic chromosome study. For the statistical analysis of the variance usual ' $\mathrm{t}$ ' tests were followed.

For Feulgen cytophotometric estimation of 4C DNA, ten fixed root-tips of each species were hydrolysed in $1 \mathrm{~N} \mathrm{HCl}$ at $60^{\circ} \mathrm{C}$ for $12 \mathrm{~min}$, washed in distilled water and stained in Schiff's reagent for $2 \mathrm{hr}$ at $14^{\circ} \mathrm{C}$; each root-tip squash was prepared in $45 \%$ acetic acid. Ten scorings were made from each slide and 4C DNA content was estimated in metaphase chromosomes using Nikon Optiphot microscope with microspectrophotometer following the method of Sharma and Sharma (1980) and applying monochromatic light at $550 \mathrm{~nm}$. In situ DNA values were obtained on the basis of optical density which were then converted to picograms (pg) using Van't Hof's (1965) 4C nuclear DNA value 67.1 pg for Allium cepa as standard. Analysis of variance (ANOVA) test (Sokal and Rohlf 1973) was performed in order to find out the significant differences of 4C DNA content among 8 species of Mammilaria. 
Observations

\section{Meiotic studies}

The scoring and statistical analysis of chiasma frequency in different species of Mammillaria showed significant interspecific variation. The haploid chromosome number $\mathrm{n}=11$ was found in all the 8 species studied (Figs. 1-8). The synchronous meiotic cell division was observed in all the species (Fig. 9). The mean chiasma per cell varied from 19.42 in $M$. boolii to 28.80 in $M$. plumosa. The chiasma per bivalent also differed significantly (Table 1 ). The highest chiasmata per bivalent (2.618) was observed in $M$. plumosa. The formation of univalent, early separation of the bivalent and presence of more than four microspores in telophase II was noted in $\boldsymbol{M}$. boolii, $M$. occidentalis and $\boldsymbol{M}$. bocasana respectively (Figs. 10-12). The highest pollen sterility (32.83\%) was found in $M$. occidentalis and the lowest pollen sterility (9.12\%) was noted in M. zeilmanniana. The mean chiasma per cell showed characteristic chiasma number.

\section{Nuclear DNA amount}

Nuclear DNA content in the root-tip cells of the 8 studied species showed significant differences from $18.42 \mathrm{pg}$ in $M$. boolii to $26.46 \mathrm{pg}$ in $M$. plumosa (Tables 1,2). The average 4C DNA content per chromosome varied among the species. The correlation values between the mean chiasma per bivalent and mean DNA content per chromosome was highly significant. The 4C DNA amount was found to be directly correlated with chiasma frequency.

\section{Discussion}

Investigations on chiasma behavior at diakinesis and metaphase I in 8 Mammillaria species confirm the high number of rod type bivalents in the PMCs of all the species. The number of bivalents was common i.e. $\mathrm{n}=11$ in all the species. The lowest chiasma per bivalent (1.765) in $M$. boolii among the studied species suggest a consequent increase of heterochromatin region leading to chiasma terminalization (Torrezan and Pagliarini 1995). Formation of univalents, early separation was observed in $M$. bocasana and $M$. boolii. The pollen sterility was the minimum (9.12\%) in $M$. zeilmanniana and the maximum $(32.83 \%)$ in $M$. occidentalis. The moderate rate of pollen sterility was about $20 \%$ in $M$. bacasana and $M$. boolii. The species of five to eight microspores during microsporogenesis in telophase II evidently, showed high percentage of sterility. Significantly, M. bocasana and $M$. boolii with univalents or spindle disturbance during cell division recorded moderate percentage of pollen sterility. All these facts suggest the genetic control of chiasma frequency (Gale and Ress 1970, Ress and Dale 1974). However, the formation of chiasma is controlled polygenetically by major genes which operate on a hierarchial system (Parker 1975). The high pollen sterility in the species having comparatively large genome size might be due to heterogenous pairing during bivalent formation in the process of spontaneous mutation (Das and Mallick 1992). The wide range of microspore formation in $M$. occidentalis with a constant nuclear DNA value around the mean of somatic cells are due to the elimination of abnormal microspore in form of nonfunctional spores during microsporogenesis.

Critical investigations of the 4C DNA amount showed significant variations between different species of Mammillaria (Tables 1, 2). The average DNA amount per chromosome also varied markedly. The chiasma frequency, however, showed a high correlation with 4C DNA amount (0.904). The high amount of DNA amount in $M$. plumosa and M. rhodantha might be due to high repetitive DNA sequences in the genome. 

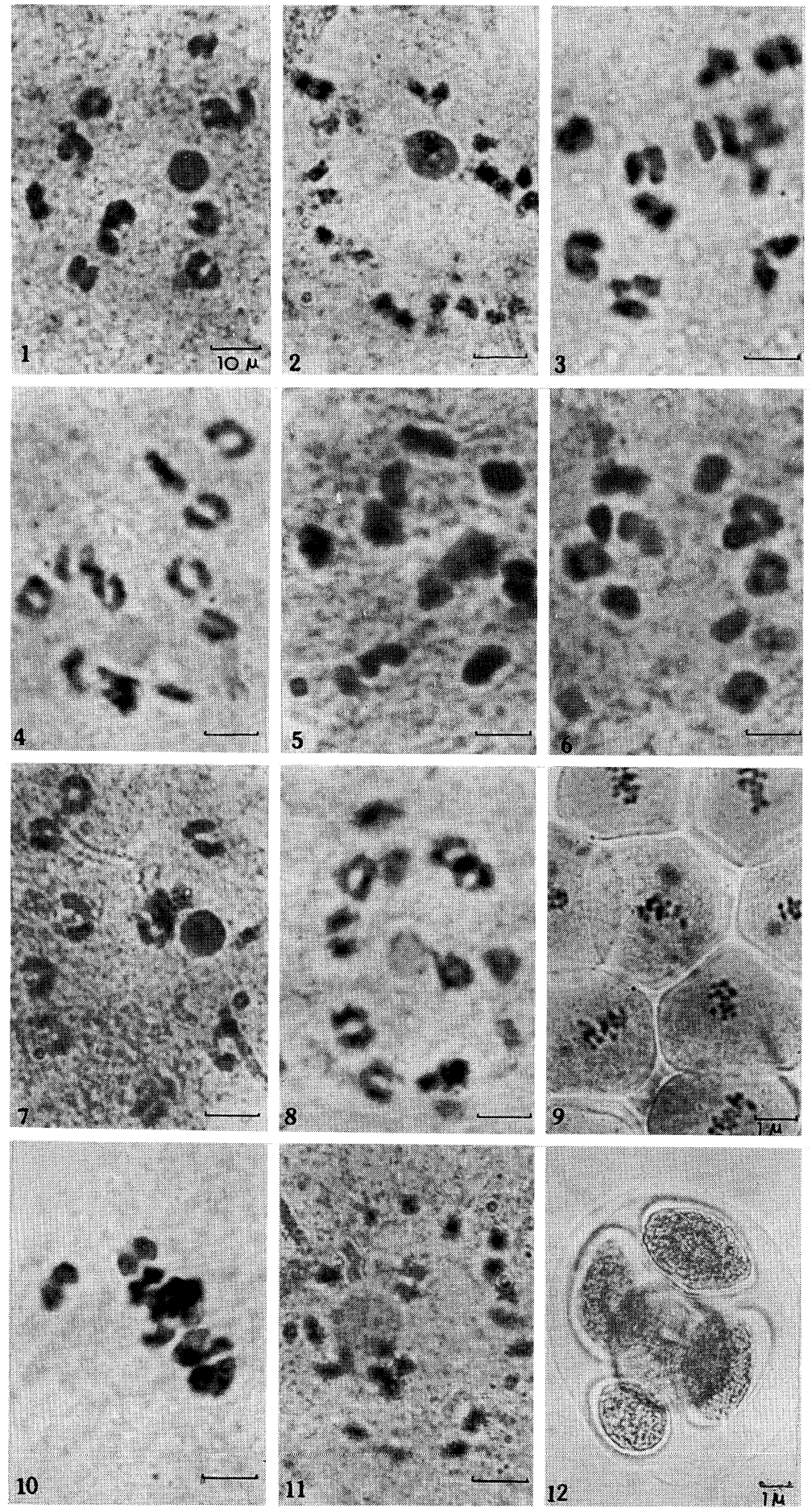

Figs. 1-8. Meiotic prophase I showing diakinesis stage in different species of Mammilaria. 1. M. bocasana. 2. M. boolii. 3. M. grandiflora. 4. M. hahniana. 5. M. occidentalis. 6. M. plumosa. 7. M. rhodantha. 8. M. zeilmanniana. Fig. 9. Synchronous cell division of meiotic metaphase $\mathrm{I}$ in $M$. zeilmanniana. Fig. 10. Early separation in meiotic metaphase $\mathrm{I}$ in $\boldsymbol{M}$. bocasana. Fig. 11. Univalent formation in M. boolii. Fig. 12. Sexad formation in M. occidentalis. 
Table 1. Haploid chromosome number, number of chiasma, pollen sterility and nuclear DNA content in 8 species of Mammillaria

\begin{tabular}{lccccc}
\hline \hline \multicolumn{1}{c}{ Species } & $\begin{array}{c}\text { Haploid } \\
\text { chromosome } \\
\text { number (n) }\end{array}$ & $\begin{array}{c}\text { Mean number } \\
\text { of chiasma per } \\
\text { cell } \pm \text { SE }\end{array}$ & $\begin{array}{c}\text { Mean number } \\
\text { of chiasma per } \\
\text { bivalent } \pm \text { SE }\end{array}$ & $\begin{array}{c}\text { Pollen sterility } \\
\text { in percentage } \\
(\%) \pm \text { SE }\end{array}$ & $\begin{array}{c}\text { 4C DNA } \\
\text { in pg } \pm \text { SE }\end{array}$ \\
\hline M. bocasana Pos. & 11 & $20.20 \pm 0.32$ & $1.83 \pm 0.04$ & $20.83 \pm 1.08$ & $19.46 \pm 0.09$ \\
M. hoolii Linds. & 11 & $19.42 \pm 0.20$ & $1.76 \pm 0.03$ & $20.31 \pm 1.01$ & $18.42 \pm 0.11$ \\
M. grandiflora Otto \& Pfeiffer & 11 & $21.76 \pm 0.24$ & $1.97 \pm 0.02$ & $16.49 \pm 0.78$ & $20.40 \pm 0.12$ \\
M. hahniana Werd. & 11 & $20.55 \pm 0.52$ & $1.86 \pm 0.02$ & $11.23 \pm 0.52$ & $19.56 \pm 0.09$ \\
M. occidentalis (Br. \& R.) Bod. & 11 & $24.05 \pm 0.24$ & $2.18 \pm 0.02$ & $32.83 \pm 1.80$ & $24.42 \pm 1.15$ \\
M. plumosa Web. & 11 & $28.80 \pm 0.23$ & $2.61 \pm 0.05$ & $10.14 \pm 0.67$ & $26.46 \pm 0.13$ \\
M. rhodantha Lk. \& O. & 11 & $22.65 \pm 0.49$ & $2.05 \pm 0.02$ & $11.68 \pm 0.23$ & $27.78 \pm 0.10$ \\
M. zeilmanniana Bod. & 11 & $26.26 \pm 0.32$ & $2.38 \pm 0.01$ & $9.12 \pm 0.23$ & $23.09 \pm 0.14$ \\
\hline
\end{tabular}

Table 2. Analysis of variance (ANOVA) test of 4C DNA content, chiasma frequency and pollen sterility in 8 species of Mammilaria

\begin{tabular}{|c|c|c|c|c|}
\hline Source & $\mathrm{DF}$ & SS & MS & $\mathbf{F}$ \\
\hline \multicolumn{5}{|l|}{ 4C DNA content } \\
\hline Between the species & 7 & 644.22 & 92.03 & $104.57^{* *}$ \\
\hline Within the species & 32 & 28.44 & 0.88 & - \\
\hline Total & 39 & & & \\
\hline \multicolumn{5}{|c|}{$\mathrm{CD}=0.52$ in $5 \%$ level; $\mathrm{CD}=1.02$ in $1 \%$ level. } \\
\hline \multicolumn{5}{|c|}{ Chiasma frequency } \\
\hline Between the species & 7 & 3.40 & 0.48 & $12.00^{* *}$ \\
\hline Within the species & 32 & 1.35 & 0.04 & - \\
\hline Total & 39 & & & \\
\hline \multicolumn{5}{|c|}{$\mathrm{CD}=0.34$ in $5 \%$ level; $\mathrm{CD}=0.43$ in $1 \%$ level. } \\
\hline \multicolumn{5}{|c|}{ Pollen sterility } \\
\hline Between the species & 7 & 824.88 & 117.84 & $155.05^{* *}$ \\
\hline Within the species & 32 & 24.33 & 0.76 & - \\
\hline Total & 39 & & & \\
\hline \multicolumn{5}{|c|}{$\mathrm{CD}=0.65$ in $5 \%$ level; $\mathrm{CD}=0.79$ in $1 \%$ level. } \\
\hline
\end{tabular}

$\mathrm{DF}=$ Degrees of freedom, $\mathrm{SS}=\mathrm{Sum}$ of squares, $\mathrm{MS}=$ Mean sum of squares, $\mathrm{F}=$ Variance ratio. $* *=$ Highly significant at $1 \%$ level.

\section{Summary}

Meiotic studies of PMCs and 4C DNA content from root tip cells of 8 species of Mammillaria of the family Cactaceae revealed significant interspecific variation in the genome. The haploid chromosome number $\mathrm{n}=11$ was recorded in $M$. bocasana, M. boolii, M. grandiflora, M. hahniana, M. occidentalis, M. plumosa, M. rhodantha and M. zeilmanniana. The chiasma frequency significantly varied from 19.42 to 28.80 per nucleus and 1.76 to 2.61 per bivalent. The formation of univalent in some of the cells, spindle anomalies i.e. early or late separation leads to the formation of pentads, sexads or octads instead of tetrads formation in the meiotic telophase II through differential pollen sterility from 9.12 to $32.83 \%$ in $M$. zeilmanniana and $M$. occidentalis respectively. The 4C DNA amount of root tip cells varied significantly from 18.42 to $27.78 \mathrm{pg}$ in $M$. bocasana and $M$. rhodantha, respectively. Significant variation in DNA amount with gross or minor alteration of chiasma frequency leads to differential heritability with genetic drift at species level. 


\section{Acknowledgements}

The authors are grateful to Department of Forest and Environment, Government of Orissa for providing necessary facilities.

\section{References}

Cullmann, W., Gotz, E. and Groner, G. 1986. The Encyclopaedia of Cacti Alphaberks, Sherbom, England, Doeset. Das, A. B. and Mallick 1992. Effect of gamma radiation on chiasma frequency in Coriandrum sativum L. and Foeniculum vulgare Mill. Perspectives in Cytology and Genetics Vol. 7, pp. 787-795. Edited by G. K. Manna and S. C. Roy.

Das, P. and Panda, P. C. 1995. Protected cultivation of cacti and other succulents. In: Advances in Horticulture Vol. 12(2), pp. 819-851. Ornamental plants (Eds. K. L. Chadha and S. K. Bhattacharjee), Malhotra Publishing House, New Delhi.

Gale, M. D. and Rees, H. 1970. Genes controlling chiasma frequency in Hordeum. Heredity 25: 393-410.

Heywood, V. H. 1985. Flowering Plants of the World. Croom Helm, London and Sydney.

Katagiri, S. 1952. Chromosome numbers and polyploidy in certain Cactaceae. Cactus and Succulent Journal 25(5): 141-143.

Panda, P. C. and Das, P. 1995. Genetic resources of cacti and other succulents. In Advances in Horticulture Vol. 12(1), pp. 243-266. Ornamental plants (Eds. K. L. Chadha and S. K. Bhattacharjee), Malhotra Publishing House, New Delhi.

Parker, J. S. 1975. Chromosome specific control of chiasma formation. Chromosoma 49: 319-406.

Remski, M. F. 1954. Cytological investigations in Mammillaria and some associated genera. Bot. Gaz. 166: $163-171$.

Ress, H. and Dale, P. J. 1974. Chiasmata and variability in Lolium and Festuca populations. Chromosoma 47: 335357.

Sharma, A. K. and Sharma, A. 1980. In: Chromosome Techniques: Theory and Practices. Third edition. Butterworths, London.

Sokal, P. R. and Rohlf, F. J. 1973. Introduction to Biostatistic. Freeman, San Francisco.

Torrezan, R. and Pagliarini, M. S. 1995. Influence of heterochromatin on chiasma localization and terminalization in maize. Caryologia 48: 247-253.

Van't Hof, J. 1965. Relationships between mitotic cycle duration, S period duration and the average rate of DNA synthesis in the root meristem cells of several plants. Expl. Cell Res. 39: 48. 